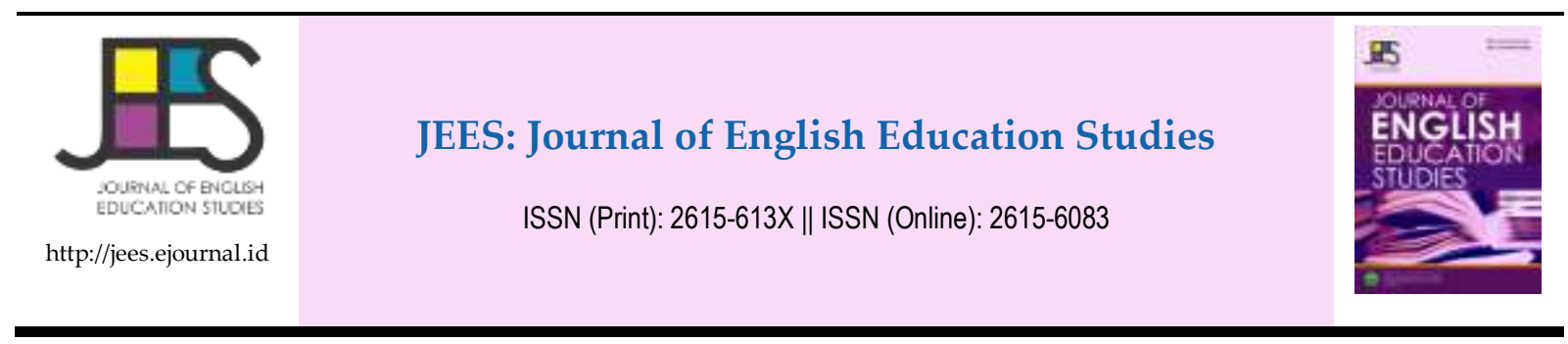

\title{
Students' Vocabulary Errors in Constructing Descriptive Text
}

\author{
Heva Rostiana ${ }^{1}$
}

${ }^{1}$ English Education Department, Teacher Training and Education Faculty, Universitas Mathla'ul Anwar Banten

\section{ARTICLE INFO}

Keywords:

Error, Vocabulary,

Descriptive Text

\begin{abstract}
This research is aimed to investigate an analysis on students' vocabulary errors in constructing descriptive text at the First Grade Students of SMK IT Al-Halim. The research is conducted through content analysis. Data of the research are taken from documentation of description text and interview with the students of SMK IT Al-Halim. Result of the research shows that there were vocabulary error in constructing descriptive text; there were lexical error, syntactical error, and discourse error. The dominant of errors is in lexical error especially in spelling errors. Vocabulary error is caused they are lacks of awareness of students in increasing mastery of the vocabulary; English words have multiple meanings and confusion, so it makes them difficult in learning English. They are also bored and lazy to look for vocabulary. In other hand, the method used by the teacher does not appropriate in learning process. Therefore, the students should enrich vocabulary by memorize ten or more of vocabulary in one day. The students also should more often open dictionary. Furthermore, and the teacher should motivate the students in learning English. Then, the teachers should give clearly, explanation and clarification when teach English especially in vocabulary for students.
\end{abstract}

This is an open access article distributed under the terms of the Creative Commons Attribution 4.0 International License, which permits unrestricted use, distribution, and reproduction in any medium, provided the original work is properly cited. @ 2021 Heva Rostiana

\section{INTRODUCTION}

English has become a great necessity to everyone who realized the importance of the language. English is learnt in every country in the world. In addition to it, many people are willing to spend their time and efforts to attend the English course. Likewise in Indonesia, English is learnt as a foreign language. It can be said that English is as the target language studied by students. It is learnt at each school and one of the subjects that always exist at all levels of formal education from kindergarten to university. Even though, it is not used as base of the rule in general education and also as language of communication in studying. Thus, it is possible for students to find difficulties in learning English. Almost of students don't like learning English. They think that it's hard to learn and to understand. Although in fact, the students must learn and master the four skills in particular on the subjects of English. The four of skills are listening, speaking, reading, and writing. Accordingly of the four skills that, on teaching English teachers should teach with a sincere heart, have high creativity and besides have good ideas. Thus learning will make more students feel happy and understand to the material in the learning process. In learning process of

\footnotetext{
${ }^{1}$ Corresponding author's address: English Education Department of Teacher Training and Education Faculty, Universitas Mathla'ul, Banten, Indonesia e-mail: anastiana15@gmail.com
} 
writing skill, to write text without know vocabulary, it is difficult to convey ideas. It is a core component of proficiency and is the basis of how well students are able to speak, listen, read, and write. We know that students often find all sorts of problems, especially in the vocabularies; among them are the lacks of awareness of students in increasing mastery of the vocabulary. Students are difficult to remember and apply the vocabulary. The meaning of words that have multiple meanings and confusion make students feel difficult. Learning techniques are not appropriate in learning conditions. Many students are bored and lazy to look for vocabulary. Therefore, Vocabulary is very important and must be mastered by the student in the four skills. Moreover, in describing the language without vocabulary cannot be delivered to the reader or listener. In learning English especially writing the student cannot avoid the mistakes that almost happened in learning process, this is occurs because they use different forms in conveying the idea of the desired message. The students have not quite grasped the new information and so continue to make errors. Error is mistake or being wrong which done by students in process learning. It is occurring where the students who do not know about the meaning of words that have multiple meanings and confusion make students difficult. The teacher must be able and have competence to find the errors, identify the errors, find the sources of errors, and make a distinction between error and mistakes. It has purpose to correct and improve the students ability. Error in vocabulary is important to analysis, because it will give form feedback that teachers can provide positive feedback, clarification, and reformulation to help students for avoiding errors in learning process. Moreover, learning from mistakes is discovering the advantages or benefits which can find out what the rules are right on the error. In constructing descriptive text, students feel difficult to pour idea. They will be hard to remember new word; therefore the students commonly make error. Errors cannot always be easily identified. It is possible that making errors may actually help learners to learn when they self-correct the errors they make.

\section{LITARATURE REVIEW}

An error is a deviation from accuracy or correctness. An error caused by a fault: the fault being misjudgment, carelessness, or forgetfulness. The important main way of investigating second language acquisition is by collecting and describing samples of student language (Ellis, 1997:15). The description may focus on the kinds of errors students make and how these errors change over time, or may identify developmental patterns by describing the stages in the acquisition of particular grammatical features such as past tense, or it may examine the variability found in learner language. Moreover to seem focusing on what students get wrong than on what they get right. There are good reasons for focusing on errors. First they are a conspicuous leather of learners' language, raising the important question of "why do learners make errors?" Second, it is useful for teacher to know what errors learners make. Third, paradoxically, it is possible that making errors may actually help learners to learn when they self-correct the errors they make. Errors are mistakes which they can't correct themselves and which therefore, need explanation (Harmer, 2007:96). Word errors generally occur after the overall syntactic structure of the sentence has been planned. It reflects gaps in a learners' knowledge and occur because the learners does not know what is correct, and they have not quite grasped the new information and so continue to make errors. The categories of errors have been identified:

a) Grammar errors are things as mistakes in verb form and tenses. (the doorbell rangs, we speaked), and in sentence structure: was the four o' clock, where the subject clause (it).

b) Discourse errors which relate to the way sentences are organized and linked in order to make whole text. For example, in the student extract above at last suggest that what follow is solution to a problem, eventually would have been better in his context.

c) Lexical errors (vocabulary errors) are mistakes at the level of individual words, in the way students put sentences together, or at the level of whole texts. 
There are other factors that make some words more difficult than others.

a) Pronunciation: Shows that words are difficult to pronounce are more difficult to learn. Potentially difficult will typically be those contain sounds that are unfamiliar to some groups of learners.

b) Spelling: Sound-spelling mismatches are likely to be errors, either of pronunciation or of spelling, can contribute to a word's difficulty.

c) Length and complexity: Long words seem to be no more difficult to learn than short ones. But, as a rule of thumb, high frequency words tend to be short in English.

d) Grammar: Also problematic is the grammar associated with the word. Especially if this differs from that of its L1 equivalent. Remembering whether a verb like enjoy, love, or hope is followed by an infinitive or an -ing can add to its difficulty.

e) Meaning: When two words overlap in meaning, learners are likely to confuse them. Words with multiple meanings, such as since and still, can also be troublesome for learners.

\section{METHOD}

In this research, the writer uses content analysis method. Content analysis is an indeph analysis using quantitative or qualitative technique of messages using a scientific method (including attention to objectivity-intersubjectivity, a priori design, reliability, validity, generalizability, replicability, and hypothesis testing) and is not limited as to the types of variables that may be measured or the context in which the messages are created or presented (Neoendrorf, 2002: 283). However, content analysis also can be defined that the use of replicable and valid method for making specific inferences from text to other states or properties of its source (Krippendorf,1969:103). Based on the definition of content analysis above, it can be conclude that content analysis method is a scientific analysis of the message content of a communication.

The sources of the data are the text which written by the students of SMK IT Al-Halim as a documentation and interview will be conducted to support the data. There is one program at the first grade. That is Administrasi Perkantoran (ADM P) program. The total of subjects is 38 students of the first grade as the source of data.

\section{RESULTS AND DISCUSSION}

In analyzing the data, the writer used Philipp Mayring Model. Activity in qualitative content analysis amongst which two approaches are central: inductive category development and deductive category development. In this research, the writer only used inductive category development. Classical quantitative content analysis has few answers to the question from where the categories come, how the system of categories is developed: "How categories are defined ... is an art. Little is written about it" (Krippendorf, 1980:76). 


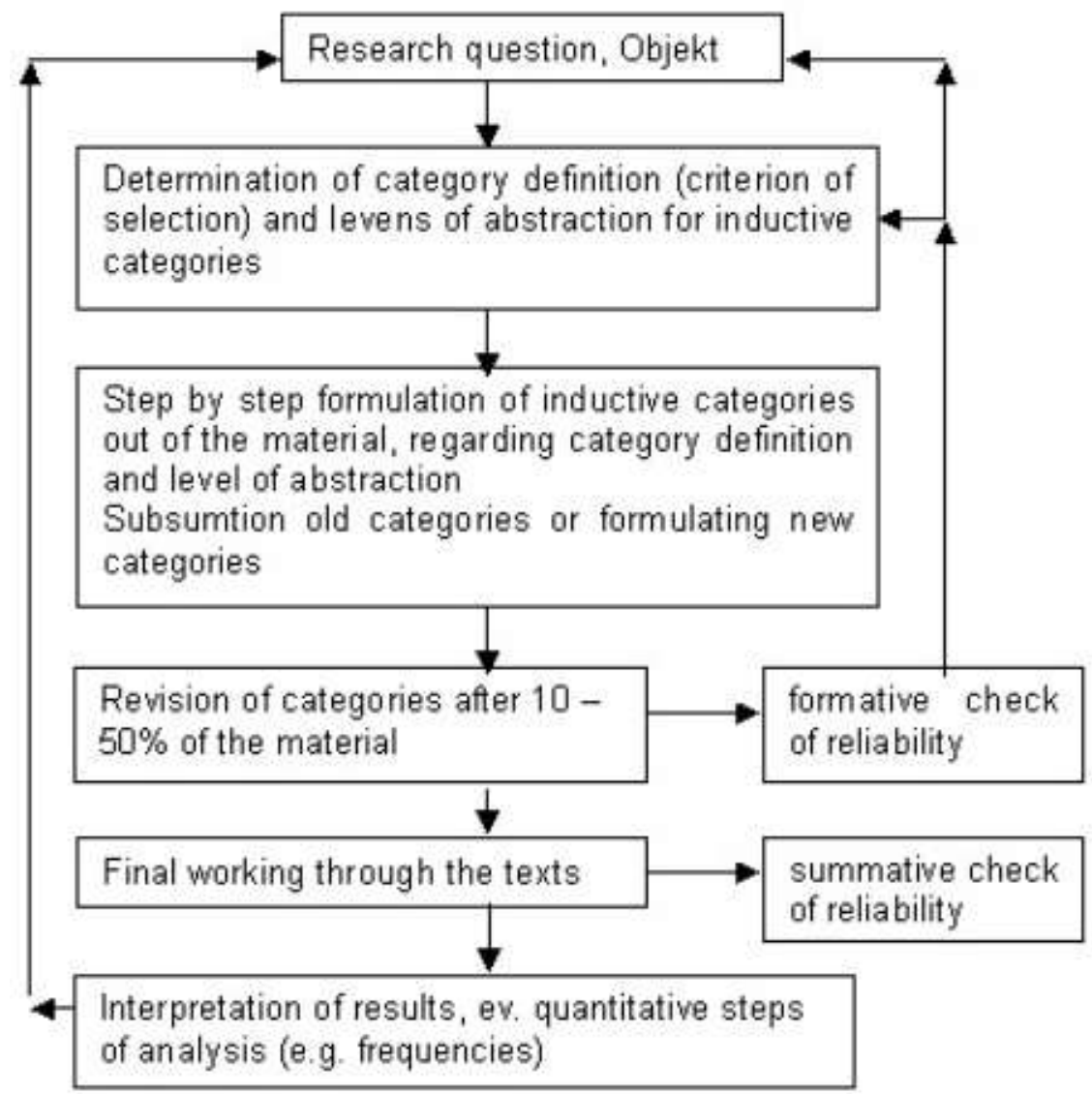

Figure 1. Inductive Model Category Development Stepts (Mayring, 2000:288)

The specific steps cannot be explained largely within this short overview. The main idea of the procedure is, to formulate a criterion of definition, derived from theoretical background and research question, which determines the aspects of the textual material taken into account. Following this criterion the material is worked through and categories are tentative and step by step deduced. Within a feedback loop those categories are revised, eventually reduced to main categories and checked in respect to their reliability. If the research question suggests quantitative aspects (e.g. frequencies of coded categories) can be analyzed.

Credibility in this research uses extension of observation. Extension of observation means the researcher returns to the field, conducts observations, interviews again with data sources ever encountered or new ones. With this observation, the relationship between the researcher and students will be more developed. And dependability or dependency is done to overcome errors in the conceptualization of research plan, data collection, findings, and reporting of research results. So that, this research require dependent auditor. The dependent auditor in this research is the supervisors.

In qualitative research the analysis technique is performed simultaneously with collection of data obtained from the field direct research analysis with content analysis model from Mayring. The following is the final result and data analysis the writer obtained by explaining the findings from the relevant field. Data related to vocabulary errors in constructing descriptive texts were collected and analyzed to produce the findings.

The results of this research give implication for the language teaching. Seen by the dominant errors finding, the teacher gives more attention to how teach vocabulary to the students in order that they use the words correctly. From discussion of finding the writers found the types of errors. The type of lexical errors has many different errors: the type of syntactical and discourse. Based on the results of analyzing data is founded in spelling. In syntactical errors is omission of to be in 
adjective. Moreover, in discourse errors is coherence errors. Based on the results was founded of errors in the first grade Administrasi Perkantoran of SMK IT Al-Halim that they made many errors on constructing descriptive text.

Table 1. Analyzing Type of Lexical Errors

\begin{tabular}{|c|l|l|l|}
\hline No & \multicolumn{1}{|c|}{$\begin{array}{c}\text { Type of Lexical } \\
\text { errors }\end{array}$} & \multicolumn{1}{|c|}{ Example of Errors } & \multicolumn{1}{c|}{ Correction } \\
\hline 1 & Spelling error & Prilly is an aktris & Prilly is an actress \\
\hline 2 & Wrong diction & Prilly have long hair & Prilly has long hair \\
\hline 3 & $\begin{array}{l}\text { Additions of } \\
\text { unnecessary word }\end{array}$ & $\begin{array}{l}\text { Prilly is not arrogant and } \\
\text { very-very kind }\end{array}$ & $\begin{array}{l}\text { Prilly is not arrogant } \\
\text { and very kind }\end{array}$ \\
\hline 4 & $\begin{array}{l}\text { Wrong in writing } \\
\text { letter }\end{array}$ & $\begin{array}{l}\text { Prilly is very Beautiful and } \\
\text { cute }\end{array}$ & $\begin{array}{l}\text { Prilly is very } \\
\text { beautiful and cute }\end{array}$ \\
\hline 5 & Omission of letter & Arogant & Arrogant \\
\hline 6 & Addition of letter & Beautifull & Beautiful \\
\hline
\end{tabular}

Table 2. Analyzing Type of Syntactical Errors

\begin{tabular}{|c|c|c|c|}
\hline No & $\begin{array}{c}\text { Type of Syntactical } \\
\text { Errors }\end{array}$ & Example of Errors & Correction \\
\hline 1 & $\begin{array}{l}\text { Omission of }(-s) \text { in } \\
\text { verb1 }\end{array}$ & $\begin{array}{l}\text { Prilly also become a } \\
\text { singer }\end{array}$ & $\begin{array}{l}\text { Prilly also becomes a } \\
\text { singer }\end{array}$ \\
\hline 2 & $\begin{array}{l}\text { Omission of (be-1) in } \\
\text { adjective }\end{array}$ & $\begin{array}{l}\text { Prilly very beautiful and } \\
\text { sweet }\end{array}$ & $\begin{array}{l}\text { Prilly is very beautiful } \\
\text { and sweet }\end{array}$ \\
\hline 3 & $\begin{array}{l}\text { Addition of (be-1) in } \\
\text { adjective }\end{array}$ & $\begin{array}{l}\text { I am is happy if I meet } \\
\text { with her }\end{array}$ & $\begin{array}{l}\text { I am happy if I meet with } \\
\text { her }\end{array}$ \\
\hline 4 & Omission of article & Prilly is singer & Prilly is a singer \\
\hline 5 & $\begin{array}{l}\text { Omission of subject } \\
\text { (the third of singular } \\
\text { person) }\end{array}$ & $\begin{array}{l}\text { Prilly is very famous, has } \\
\text { long hair and straight } \\
\text { hair }\end{array}$ & $\begin{array}{l}\text { Prilly is very famous. She } \\
\text { has long hair and straight } \\
\text { hair }\end{array}$ \\
\hline 6 & Disordering & Prilly is a girl beautiful & Prilly is a beautiful girl \\
\hline 7 & $\begin{array}{l}\text { Ungrammatical } \\
\text { sentence }\end{array}$ & $\begin{array}{l}\text { Prilly much in like all } \\
\text { people }\end{array}$ & $\begin{array}{l}\text { Prilly is liked many } \\
\text { people }\end{array}$ \\
\hline
\end{tabular}

Table 3 Analyzing Type of Discourse Errors

\begin{tabular}{|c|l|l|l|}
\hline No & $\begin{array}{l}\text { Type of Discourse } \\
\text { errors }\end{array}$ & \multicolumn{1}{|c|}{ Example of Errors } & \multicolumn{1}{|c|}{ Correction } \\
\hline 1 & $\begin{array}{l}\text { Omission } \\
\text { Conjunction }\end{array}$ & $\begin{array}{l}\text { Prilly is an actress, also } \\
\text { becomes a singer. }\end{array}$ & $\begin{array}{l}\text { Prilly is an actress. She } \\
\text { also becomes a singer. }\end{array}$ \\
\hline 2 & $\begin{array}{l}\text { Omission } \\
\text { punctuation }\end{array}$ & $\begin{array}{l}\text { Prilly is an actress also is } \\
\text { a singer Prilly is very } \\
\text { beautiful and cute }\end{array}$ & $\begin{array}{l}\text { Prilly is an actress and } \\
\text { she is a singer. Prilly is } \\
\text { very beautiful and cute. }\end{array}$ \\
\hline 3 & Coherence error & $\begin{array}{l}\text { Prilly is a beautiful cute } \\
\text { actrist, long, hair girl. is } \\
\text { very kind because many } \\
\text { people like her. She has } \\
\text { long hair and black hair } \\
\text { and is smart student in } \\
\text { her class many people } \\
\text { know her because is } \\
\text { actrist and she has }\end{array}$ & $\begin{array}{l}\text { Prilly is an actress; she is } \\
\text { a beautiful and cute girl. } \\
\text { Prilly has long hair. Many } \\
\text { people love her, because } \\
\text { she is smart in her class. }\end{array}$ \\
\hline
\end{tabular}




\begin{tabular}{|l|l|l|}
\hline & $\begin{array}{l}\text { beautiful voice so many } \\
\text { people like her }\end{array}$ & \\
\hline
\end{tabular}

\section{CONCLUSION AND SUGGESTION}

Based on the results of the research, the writer found the kind of errors and the causes of errors made by students of the first grade Administrasi Perkantoran at SMK IT Al-Halim. The kinds of errors are lexical errors: Lexical error consists of spelling errors, wrong diction, and addition of unnecessary word, wrong in writing letter, omission of letter and addition of letter. Then, syntactical errors consist of omission of (-s) in verb 1, omission of (be-1) in adjective, addition of (be-1) in adjective, omission of article, omission of subject (the third of singular person), disordering and ungrammatical sentence. On the other hand, the kind of errors is discourse errors. It is consists of omission conjunction, omission punctuation, and coherence errors.

There are many causes of vocabulary errors done by students in constructing descriptive text. First, the students do not like the English subject, especially in learning vocabulary. Second, the students are the lacks of awareness of students in increasing mastery of the vocabulary. Third, the students feel difficult when learning English, because they are lack vocabulary. Fourth, many students are bored and lazy to look for vocabulary. Fifth, many of words have multiple meanings and confusion. So, it makes students feel difficult. Sixth, many students feel bored in learning English, because the method used by the teacher does not appropriate in learning process.

Therefore, students of the first grade Administrasi Perkantoran at SMK IT Al-Halim have done errors in processing learning English, especially in learning vocabulary in constructing descriptive text. Those errors cause many students do not master vocabulary, because they do not usually learn more

\section{REFERENCES}

Arikunto, S. (2010). Prosedur penelitian suatu pendekatan praktik. PT Rineka Cipta.

Blachowicz, C., Fithe writersr. P. J. Teaching vocabulary in all clasrooms. Pearson education, Inc.

Brown. (2007). Teaching by principles an interactive approach to language pedagogy. Longman.

Haris. (1996). The Psychology of Language. Prentice Hall.

Harmer, J. (2007).How to Teach English. Longman.

James. C. (1998). Errors in Language Learning and Use: Exploring Error Analysis. Addison Wesley Longman Inc.

Kristina F. Y.(2014). Learner Errors in Descriptive Text. The thesis at Muhamadiah University of Surakarta.

Jay, B. T. (2003). The Psychology of Language.Prentice Hall. 